\title{
OCCUPATIONAL ACCIDENTS AND HEALTH-RELATED QUALITY OF LIFE: A STUDY IN THREE HOSPITALS
}

\author{
Claudia Maria Monteiro ${ }^{1}$ \\ Maria Cecília Cardoso Benatti ${ }^{2}$ \\ Roberta Cunha Matheus Rodrigues ${ }^{3}$
}

Monteiro CM, Benatti MCC, Rodrigues RCM. Occupational accidents and health-related quality of life: a study in three hospitals. Rev Latino-am Enfermagem 2009 janeiro-fevereiro; 17(1):101-107.

This study analyzed the occurrence of occupational accidents among hospital workers between 2000 and 2005 and health-related quality of life of a sample of injured workers in 2005. Data obtained through occupational accident reports indicated 286 injured workers. In typical accidents (91.6\%), accidents with piercing-cutting instruments affected $68.5 \%$ of workers. The results related to health-related quality of life obtained from 61 injured workers in 2005, through the SF-36 Medical Outcomes Study 36 - item short form health survey, evidenced high average values in most of the analyzed domains, while the lowest score observed was Vitality and Bodily Pain. No significant differences in health-related quality of life were found among injured workers from the three studied hospitals.

DESCRIPTORS: accidents, occupational; quality of life; workers; hospitals

\section{ACCIDENTES DE TRABAJO Y CALIDAD DE VIDA: UN ESTUDIO EN TRES HOSPITALES}

Se trata de un estudio, realizado en el período 2.000-2.005, entre trabajadores de instituciones hospitalarias, que tenían diferentes modalidades de organización e instrumentalización, que comparó la ocurrencia de accidentes de trabajo y con la calidad de vida relacionada a la salud, en una muestra de accidentados en el año de 2.005. Los datos obtenidos posibilitaron identificar 286 trabajadores accidentados a partir de las comunicaciones de Accidentes de Trabajo. Entre los accidentes típicos (91,6\%), los con objetos punzo cortantes alcanzaron el $68,5 \%$ del grupo estudiado. Los resultados relativos a la calidad de vida relacionada con la salud, obtenidos con la auto aplicación del cuestionario SF-36 (Medical Outcomes Study 36 - item short form health survey) en los 61 trabajadores accidentados, en 2.005, muestran valores promedio elevados en la mayoría de los dominios analizados, siendo constatada una puntuación menor en los dominios Vitalidad y Dolor. No hubo diferencia significativa en la calidad de vida entre los trabajadores accidentados de los tres hospitales estudiados.

DESCRIPTORES: accidentes de trabajo; calidad de vida; trabajadores; hospitales

\section{ACIDENTE DO TRABALHO E QUALIDADE DE VIDA RELACIONADA À SÁUDE: UM ESTUDO EM TRÊS HOSPITAIS}

Trata-se de estudo que comparou a ocorrência de acidente do trabalho em trabalhadores de instituições hospitalares, com diferentes modalidades organizacionais, no período de 2000-2005, e a qualidade de vida relacionada à saúde de uma amostra de acidentados do ano 2005. Os dados obtidos possibilitaram identificar 286 trabalhadores acidentados a partir da Comunicação de Acidentes do Trabalho. Dos acidentes típicos (91,6\%), aqueles com objetos perfurocortantes atingiram $68,5 \%$ dos trabalhadores acidentados. Os resultados relativos à qualidade de vida relacionada à saúde, obtidos por auto-aplicação do SF-36 Medical Outcomes Study 36 Item short form health survey, junto aos 61 trabalhadores acidentados, em 2005, mostraram valores médios elevados na maioria dos domínios analisados, sendo constatada menor pontuação nos domínios Vitalidade e Dor. Não houve diferença significante na qualidade de vida relacionada à saúde entre os trabalhadores acidentados dos três hospitais estudados.

DESCRITORES: acidentes de trabalho; qualidade de vida; trabalhadores; hospitais

${ }^{1}$ RN, M.Sc. in Nursing, Faculty at Instituição de Ensino São Francisco, Brazil, e-mail: claudia.m.monteiro@uol.com.br; ${ }^{2}$ RN, Associate Professor at Faculdade de Ciências Médicas da Universidade Estadual de Campinas, Brazil, e-mail: mcbenatti@uol.com.br; ${ }^{3}$ RN, Associate Professor at Faculdade de Ciências Médicas da Universidade Estadual de Campinas, Brazil, e-mail: robertar@fcm.unicamp.br. 


\section{INTRODUCTION}

Work plays an essential role in life and health conditions of individuals, families and the population in general. However, the work organization and its conditions can cause weariness, diseases and occupational accidents ${ }^{(1)}$.

According to the Social Security Law 8213, from July $24^{\text {th }} 1991$, Occupational Accidents (OA) occur during work tasks, causing physical lesion or functional disorder that leads to death, loss, or temporary or permanent reduction of work capacity. Commuting accidents occur during transportation from home to work or vice-versa. Professional disease, also considered occupational accident, is produced or triggered by the exercise inherent to the activity itself $^{(1)}$.

Occupational accidents are the most reported injuries to workers' health all over the world, even taking into account under-notification. In Brazil, the law (8213, from July $24^{\text {th }} 1991$ - Social Security) requires that occupational accidents be reported to the Brazilian Social Security Institute (INSS). Occupational accident notifications are filled out and forwarded after every and any accident occurred in the work environment.

Work in hospital units has been associated to workers' overload and weariness, especially in public hospitals, which usually attend high demands, mainly of users from the Brazilian Single Health System (SUS). In this scenario, work overload can affect workers' Quality of Life (QoL).

The World Health Organization understand QoL as "the individuals' perception of their position in life, in the context of the culture and value system in which they live and in relation to their goals, expectations, standards and concerns" (2).

However, the advancement of research on QoL has originated focal definitions, that is, referring to only one or a small number of quality of life components. Thus, the concept of health-related quality of life (HRQOL) has emerged. It is defined as value attributed to life, weighted by functional deteriorations, perceptions and social conditions triggered by diseases, injuries, treatments, and political and economic organization of the care system ${ }^{(3)}$.

Even though there are studies in literature that relate factors existent in the work environment to occupational accidents ${ }^{(1)}$, there is no research investigating $\mathrm{QoL}$, and more specifically $\mathrm{HRQOL}$, in health professionals injured by occupational accidents working in hospitals. Considering that work conditions can differ among diverse hospital organization structures, this study aimed to evaluate the occurrence of occupational accidents between 2000 and 2005 in workers of hospitals with different organizational modes, as well as health-related quality of life in workers injured by occupational accidents in 2005

\section{METHOD}

This study was carried out in two stages. The first stage was retrospective and provided a profile of occupational accident victims between 2000 and 2005 in three hospitals in the interior of Sao Paulo, Brazil. The second phase was cross-sectional and aimed to analyze HRQoL of a sample of subjects injured by occupational accidents in 2005.

The hospitals were (A) private, (B) philanthropic and (C) public. Hospital A had 105 beds for general care and maternity, 360 employees, attended private clients and patients with some health insurances. Hospital B had 181 beds for general care and maternity, with 457 employees, attended through private health insurances and SUS. Hospital $C$ had 42 beds, 300 employees, attended only SUS users. Even though these hospitals were not teaching hospitals, the three institutions received students from private schools to develop practical activities (supervised training).

According to the Occupational Accident Reports (OAR), of the total of 1,117 workers from the three hospitals (basis - 2005), all hired under the Consolidation of Brazilian Labor Laws - (CLT), 251 workers were injured by occupational accidents between 2000 and 2005, totaling 286 occurrences. Injured workers were from the medical, nursing and support services (kitchen, laundry, cleaning and maintenance). The HRQoL was only evaluated among workers who were regularly exerting their functions in $2005(n=61)$.

Data collection was carried out according to two stages:

1. Retrospective data were obtained from OARs of hospitals between 2000 and $2005(n=286)$. These data allowed the researchers to determine the sociodemographic profile of injured workers and their respective occupational accidents;

2. HRQoL was evaluated among workers injured in 2005 ( $n=61$ ) through the validated Brazilian version ${ }^{(5)}$ of the Medical Outcomes Study 36- Item Short-Form Health Survey ${ }^{(4)}$. It is a questionnaire for self- 
completion, composed of eight scales: Physical Functioning, Role Physical, Bodily Pain, General Health Perception, Vitality, Social Functioning, Role Emotional, Mental Health and an additional question for comparative evaluation between current health status and that of the year before. The final score for each domain ranges from 0 to 100 , in which 0 corresponds to the worst and 100 to the best possible health status.

The study was approved by the Research Ethics Committee at the State University of Campinas. Workers were invited to participate in the study and asked to sign a free and informed consent term.

Data were first inserted in the Microsoft Excel program 2002 and, later, the following analyses were performed through the Statistical Analysis System SAS version 8.02 (1999-2001) USA: descriptive, variance (Anova on ranks), followed by Tukey's and association (Chi-square) tests. Reliability, according to internal consistency, was evaluated by Cronbach's alpha, with a satisfactory alpha coefficient set at > $0.70^{(6)}$. The level of significance adopted was $5 \%$ ( $p$ valor $<0.05)$.

\section{RESULTS}

There were 1,117 workers in the three studied hospitals between 2000 and 2005 (basis 2005). Two hundred and six occupational accidents were reported in the period, which injured 251 workers (35 workers were affected by more than one accident). The total distribution of workers and number of occupational accidents per institution is presented in Table 1.

Table 1 - Distribution of workers and occupational accidents in to three hospitals in São Paulo, Brazil, 2000-2005

\begin{tabular}{ccc}
\hline Hospital & \multicolumn{2}{c}{ Injured workers } \\
& $\mathbf{n}$ & $\%^{*}$ \\
\hline A $(n=360)$ & 73 & 20.2 \\
B $(n=457)$ & 120 & 26.2 \\
C $(n=300)$ & 93 & 31 \\
Total $(n=1117)$ & 286 & 25.6 \\
\hline
\end{tabular}

* \% of accidents according to the number of workers per institution

Although a larger number of occupational accidents was observed in hospital B, hospital C presented the highest percentage (31\%) of occupational accidents in the studied period when considering the number of occupational accidents per number of workers.

The socio-demographic and occupational profile of workers injured between 2000 and 2005 is presented in Table 2.

Table 2 - Distribution of injured workers according to socio-demographic and occupational characteristics in three hospitals in Sao Paulo, Brazil, 2000-2005 ( $n=251)$

\begin{tabular}{|c|c|c|c|c|c|c|c|c|c|c|c|}
\hline \multirow{3}{*}{ Variables } & \multicolumn{10}{|c|}{ Hospitals } & \multirow{3}{*}{$p$-value } \\
\hline & \multicolumn{3}{|c|}{ A } & \multicolumn{3}{|c|}{ B } & \multirow{2}{*}{$\frac{C}{N(\%)}$} & \multicolumn{3}{|c|}{ Total } & \\
\hline & N (\%) & 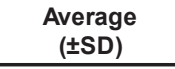 & Median & N (\%) & $\begin{array}{c}\text { Average } \\
( \pm S D)\end{array}$ & Median & & Average ( $\pm S D$ ) & Median & n (\%) & \\
\hline \multicolumn{12}{|l|}{ Gender } \\
\hline Female & $59(95.1)$ & & & $92(80.7)$ & & & $59(78.6)$ & & & $210(83.6)$ & $0.009^{* *}$ \\
\hline Age & & $30.8( \pm 8.9)$ & 28 & & $33( \pm 9.7)$ & 32 & & $35.4( \pm 9.4)$ & 36 & & $\begin{array}{c}0.011^{* * *} \\
\mathrm{~A} \neq \mathrm{C}\end{array}$ \\
\hline Wage* & & $654.9( \pm 239.4)$ & 616 & & $565.4( \pm 436.3)$ & 493 & & $565.9( \pm 425.1)$ & 433 & & $\begin{array}{c}0.0001^{* * *} \\
(A \neq B \text { and } \\
C ; B \neq C)\end{array}$ \\
\hline \multicolumn{12}{|l|}{ Category } \\
\hline $\begin{array}{l}\text { Support } \\
\text { Personnel }\end{array}$ & $18(29)$ & & & $29(25.4)$ & & & $20(26.7)$ & & & $67(26.7)$ & \\
\hline $\begin{array}{l}\text { Nursing } \\
\text { Technicians }\end{array}$ & $15(24.2)$ & & & $09(7.9)$ & & & $0(0)$ & & & $24(9.6)$ & $\begin{array}{c}<0.0001^{\dagger} \\
(A \neq B \\
A \neq C)\end{array}$ \\
\hline Physician/nurse & $01(1.6)$ & & & $05(4.4)$ & & & $12(16)$ & & & $18(7.2)$ & $\begin{array}{c}<0.0001^{\dagger} \\
(C \neq A \\
C \neq B)\end{array}$ \\
\hline
\end{tabular}

*(Currency - R\$); **Fisher's exact test; *** Anova ranks and Tukey's test; ${ }^{\dagger}$ Chi-square

The female gender, average age of $33.1( \pm 9.3)$ years old and average wage of $595.4( \pm 366.9)$ prevailed in the sample. Analyzing the distribution of accidents by professional category, it was observed that nursing 
auxiliaries presented the largest number of accidents with $56.6 \%$ of cases; the categories physician/nursing together presented the smallest number of accidents $(7.2 \%)$ (Table 2). Although, in general, the three hospitals presented the same tendency in the distribution of socio-demographic variables, some differences were observed among them. A higher proportion of injured women was identified at hospital A $(p=0.009$, Fisher's exact test). The average age of injured workers in hospital A was significantly lower than in hospital $C(p=0.011$; Anova on ranks). Regarding wage, it was observed that workers in hospital A presented significantly higher wages than workers in hospital B and C $(p<0.0001$; Anova on ranks), and workers in hospital B presented significantly higher wages than those in hospital C. In terms of professional category, the nursing technicians in hospital A presented the larger proportion of accidents compared to technicians from hospitals B and C $(p<0.0001 ;$ Chi-square).

The distribution analysis of occupational accidents over the years, months, weekdays and work shifts, is presented in Table 3. Except for 2003, a gradual increase of accidents reported between 2000 and 2005 is observed, with the largest number of accidents occurring in the second semester (52.1\%). Regarding the distribution over the week, the largest number of accidents occurred between Mondays and Thursdays (62.9\%).

Table 3 - Distribution of accidents according to the year, month, day of week and shift in three hospitals in Sao Paulo between 2000 and $2005(n=286)$

\begin{tabular}{|c|c|c|c|c|c|c|}
\hline \multirow{4}{*}{ Variables } & \multirow{4}{*}{ Categories } & \multicolumn{5}{|c|}{ Occupational Accidents } \\
\hline & & \multirow{3}{*}{$\begin{array}{l}\mathbf{A} \\
\mathrm{n}\end{array}$} & \multicolumn{3}{|c|}{ Hospitals } & \multirow[b]{3}{*}{$\%$} \\
\hline & & & B & C & Total & \\
\hline & & & $\mathbf{n}$ & $\mathbf{n}$ & $\mathrm{n}$ & \\
\hline \multirow{6}{*}{ Year } & 2000 & 1 & 13 & 9 & 23 & 8 \\
\hline & 2001 & 6 & 7 & 19 & 32 & 11.3 \\
\hline & 2002 & 16 & 20 & 17 & 53 & 18.5 \\
\hline & 2003 & 10 & 18 & 11 & 39 & 13.6 \\
\hline & 2004 & 14 & 33 & 20 & 67 & 23.4 \\
\hline & 2005 & 26 & 29 & 17 & 72 & 25.2 \\
\hline \multirow{2}{*}{ Month } & $\begin{array}{l}\text { January to } \\
\text { June }\end{array}$ & 30 & 54 & 53 & 137 & 47.9 \\
\hline & $\begin{array}{c}\text { July to } \\
\text { December }\end{array}$ & 43 & 66 & 40 & 149 & 52.1 \\
\hline \multirow{8}{*}{$\begin{array}{l}\text { Day of } \\
\text { the week }\end{array}$} & Sunday & 6 & 21 & 9 & 36 & 12.6 \\
\hline & Monday & 14 & 17 & 17 & 48 & 16.8 \\
\hline & Tuesday & 15 & 15 & 18 & 48 & 16.8 \\
\hline & Wednesday & 8 & 18 & 19 & 45 & 15.7 \\
\hline & Thursday & 10 & 19 & 10 & 39 & 13.6 \\
\hline & Friday & 9 & 15 & 9 & 33 & 11.5 \\
\hline & Saturday & 11 & 15 & 10 & 36 & 12.6 \\
\hline & lgnored & 0 & 0 & 1 & 1 & 0.4 \\
\hline \multirow{2}{*}{ Shift } & $7-19$ & 40 & 87 & 75 & 202 & 70.6 \\
\hline & $19-7$ & 33 & 33 & 18 & 84 & 29.4 \\
\hline
\end{tabular}

Regarding the shift when accidents occurred (Table 3), at the three studied hospitals, the highest frequency was found between 7AM and 7PM (70.6\%).

The analysis of 286 OARs showed that the highest percentage found, regarding the type of accident, was that of typical accidents (91.6\%), which are accidents that occur during the work process (Table 4).

Table 4 - Distribution of accidents according to type, site, body part affected, causing agent and activity, in three hospitals in Sao Paulo, 2000-2005 $(n=286)$

\begin{tabular}{|c|c|c|c|c|c|c|}
\hline \multirow{4}{*}{ Variables } & \multirow{4}{*}{ Categories } & \multicolumn{5}{|c|}{ Occupational Accidents } \\
\hline & & \multicolumn{5}{|c|}{ Hospitals } \\
\hline & & $\mathbf{A}$ & B & C & Total & \\
\hline & & $\mathbf{n}$ & $\mathbf{n}$ & $\mathbf{n}$ & $\mathbf{n}$ & $\%$ \\
\hline \multirow{3}{*}{ Type } & Typical accident & 63 & 114 & 85 & 262 & 91,6 \\
\hline & Commuting accident & 10 & 6 & 7 & 23 & 8 \\
\hline & Occupational disease & 0 & 0 & 1 & 1 & 0,4 \\
\hline \multirow{6}{*}{ Site } & $\begin{array}{l}\text { Hospitalization and } \\
\text { outpatients clinic }\end{array}$ & 44 & 58 & 43 & 151 & 52,8 \\
\hline & $\begin{array}{l}\text { Surgical center, material } \\
\text { center and ITU }\end{array}$ & 6 & 34 & 16 & 56 & 19,6 \\
\hline & Support services & 9 & 18 & 12 & 39 & 13,6 \\
\hline & On the way & 10 & 6 & 7 & 23 & 8 \\
\hline & Specialized services & 2 & 3 & 6 & 11 & 3,9 \\
\hline & Others & 2 & 2 & 2 & 6 & 2,1 \\
\hline \multirow{4}{*}{$\begin{array}{l}\text { Body part } \\
\text { affected }\end{array}$} & Superior limbs & 53 & 91 & 63 & 207 & 72,4 \\
\hline & Inferior limbs & 6 & 13 & 2 & 21 & 7,6 \\
\hline & Spine & 1 & 3 & 9 & 13 & 4,6 \\
\hline & Others & 12 & 13 & 19 & 44 & 15.4 \\
\hline \multirow{6}{*}{$\begin{array}{l}\text { Causing } \\
\text { agent }\end{array}$} & Piercing cutting & 54 & 87 & 55 & 196 & 68,5 \\
\hline & Physical Structure & 5 & 19 & 7 & 31 & 10,9 \\
\hline & On the way & 10 & 3 & 9 & 22 & 7,7 \\
\hline & Body fluids & 4 & 9 & 5 & 18 & 6,3 \\
\hline & Physical effort & 0 & 1 & 11 & 12 & 4,2 \\
\hline & Patient's aggression & 0 & 1 & 6 & 7 & 2,4 \\
\hline \multirow{10}{*}{$\begin{array}{l}\text { Developed } \\
\text { activity }\end{array}$} & Administration of medication & 27 & 38 & 27 & 92 & 32,1 \\
\hline & $\begin{array}{l}\text { Manipulation of venous } \\
\text { access }\end{array}$ & 9 & 17 & 10 & 36 & 12,6 \\
\hline & On the way & 12 & 6 & 7 & 25 & 8,8 \\
\hline & Cleaning the unit/garbage & 8 & 11 & 5 & 24 & 8,4 \\
\hline & Procedural room circulation & 2 & 13 & 7 & 22 & 7,7 \\
\hline & Attending patient & 3 & 6 & 9 & 18 & 6,3 \\
\hline & Washing material & 0 & 10 & 5 & 15 & 5,3 \\
\hline & Capillary glucose procedure & 5 & 5 & 2 & 12 & 4,2 \\
\hline & Surgical procedure & 0 & 0 & 9 & 9 & 3,1 \\
\hline & Others & 5 & 14 & 14 & 33 & 11,5 \\
\hline
\end{tabular}

According to accident site (Table 4), the hospitalization unit (room/bed and nursing station) $(36.3 \%)$ and the outpatient clinic (16.5\%) together presented the highest level of accidents (52.8\%). The workers' body part most affected by OA was superior members (72.4\%), especially fingers and hands $(65.8 \%)$. 
Regarding causal agent (Table 4), accidents with piercing-cutting materials were the most relevant, responsible for $68.5 \%$ of accidents. Injuries with needles and improperly discarded needles and blades reached $57.8 \%$ and $16.8 \%$ of these cases, respectively.

The 61 workers injured in 2005 and who were regularly active in their functions during this period are mostly women $(85.2 \%)$, with an average age of
33 years ( \pm 8.3$)$, nursing auxiliaries $(49.2 \%)$, followed by support service functions (23\%), nursing technicians $(18 \%)$, physicians $(8.2 \%)$ and nurses $(1.6 \%)$. Most of the accidents in this sample (70.5\%) occurred during the day, between 7AM and 7PM.

HRQol measures obtained with the application of the SF-36, as well as Cronbach's alpha values for the 61 injured workers are presented in Table 5.

Table 5 - Descriptive analysis of SF-36 domains and Cronbach's alpha of injured workers in three hospitals in Sao Paulo in $2005(n=61)$

\begin{tabular}{|c|c|c|c|c|c|c|c|c|c|c|c|}
\hline \multirow{2}{*}{ Domains SF - 36} & \multicolumn{3}{|c|}{ Hospital A ( $n=23)$} & \multicolumn{3}{|c|}{ Hospital B $(n=24)$} & \multicolumn{3}{|c|}{ Hospital C $(n=14)$} & \multirow{2}{*}{ p-value* } & \multirow{2}{*}{$\begin{array}{l}\text { Cronbach's } \\
\text { alpha }\end{array}$} \\
\hline & Average & SD & Median & Average & SD & Median & Average & SD & Median & & \\
\hline Physical functioning & 95 & 6.6 & 100 & 93.5 & 8.4 & 95 & 91 & 8.5 & 92.5 & 0.3345 & 0.57 \\
\hline Role physical & 81.5 & 31.3 & 100 & 91.6 & 14.1 & 100 & 76.7 & 35.9 & 100 & 0.5114 & 0.78 \\
\hline Bodily Pain & 79.2 & 22.6 & 84 & 82.3 & 17.5 & 84 & 67.8 & 19.9 & 62 & 0.1245 & 0.86 \\
\hline General health perception & 85 & 14.9 & 87 & 85.7 & 15.2 & 90 & 78.6 & 14.6 & 81 & 0.2310 & 0.68 \\
\hline Vitality & 74.5 & 17.3 & 80 & 77.2 & 11.3 & 80 & 69.2 & 18.6 & 77.5 & 0.5800 & 0.81 \\
\hline Social functioning & 84.2 & 20 & 100 & 88 & 11.4 & 87,5 & 76.7 & 30.1 & 93.7 & 0.9318 & 0.63 \\
\hline Role emotional & 87 & 28 & 100 & 90.2 & 15.5 & 100 & 83.3 & 31.3 & 100 & 0.9053 & 0.64 \\
\hline Mental health & 81 & 15.5 & 84 & 85 & 10.1 & 84 & 76.8 & 22.8 & 84 & 0.7858 & 0.88 \\
\hline
\end{tabular}

*Anova on ranks

The HRQL domains measured by SF-36 presented satisfactory values of Cronbach's alpha, between 0.63 and 0.86 , except for the Physical functioning domain (0.57), evidencing satisfactory reliability according to the homogeneity criterion.

In general, average scores above 70 were observed for the majority of domains in the three subsamples. Considering that scores in each domain can vary from 0 to 100 , the results show that injured workers presented high average values in most of the analyzed domains. Bodily Pain and Vitality presented the lowest scores in the three studied hospitals.

The comparison of HRQoL scores among the studied hospitals shows that, although there were no statistically significant differences among the scores of the three hospitals, injured workers in hospital C presented the lowest average scores in all analyzed domains.

\section{DISCUSSION}

This study aimed to compare the occurrence of occupational accidents between 2000 and 2005 and health-related quality of life of workers injured at three hospitals in Sao Paulo, Brazil in 2005.
According to the distribution of the total number of workers per institution and number of beds at the studied hospitals, hospital B (philanthropic) had $2.5 \%$ of workers per bed, hospital A (private) had $3.4 \%$ and hospital C (public) $7.1 \%$. This result can be explained by the personnel hiring policy and characteristics of each hospital regarding care and service delivery.

Data appointed the predominance of women among injured workers $(83.6 \%)$, which is in accordance with data reported by other authors ${ }^{(7-8)}$. The majority of nursing workers and support personnel working in hospitals is female, so that women are the most exposed to risk situations, often assuming tasks that are not appropriate to their physical structure. According to the workers' age, the results show that hospital A (private) had significantly younger workers than those in hospital $C$ (public), which may reflect the adopted personnel hiring criteria (interviews $x$ official examinations). A great variation of age among injured workers is reported in literature ${ }^{(7-9)}$, which suggests that the occurrence of accidents should be investigated according to occupational activity instead of age.

In terms of professional category (Table 2), nursing auxiliaries were the most affected by accidents. 
A search in 55 published studies ${ }^{(8)}$ also showed nursing auxiliaries as the most affected category. These results are probably related to accidents during medication administration, an activity predominantly performed by nursing auxiliaries.

Regarding the year of accident, results appoint that the progressive increase in accident notifications is probably due to employers' better knowledge of the existent legislation, since the report of occupational accidents is mandatory.

The result indicating that occupational accidents occurred predominantly from Mondays to Thursdays $(62.9 \%)$ can be explained by the large number of people circulating in the units: workers, patients, visitors, professors and trainees. This leads to the conclusion that, the larger the number of people around at the same time and place, the higher the number of risks causing incidents, "almost accidents" and even occupational accidents. Similar data are found in Brazilian literature ${ }^{(1,10)}$.

According to other studies, piercing-cutting material was also the leading cause of hospital accidents $^{(1,9)}$. Injuries with this kind of material are extremely dangerous because they can transmit more than 20 different pathogens, among them Hepatitis $B$ and $C$ and the human immunodeficiency virus $(\mathrm{HIV})^{(1,8,11)}$.

The results show, in relation to the workers' HRQoL, high average values in the large majority of analyzed domains, while the smallest scores were found for Bodily Pain and Vitality domains in the three studied hospitals. Other studies measuring HRQoL among health workers also evidence high levels of commitment of the Vitality and Bodily Pain domains ${ }^{(12-13)}$.

The high HRQoL scores obtained in this study can be explained by the fact that a generic HRQoL assessment instrument was used. The instrument may not have been efficient to discriminate the extent to which QoL was committed, because of the work specificities, especially those related to occupational accidents.

Although there are studies in literature investigating $\mathrm{HRQOL}$ in health workers $^{(12-13)}$, it has been little explored among health professionals injured at work.

It is important to highlight that, even though there were no significant differences in the comparison of HRQoL among injured workers in the three hospitals, the lowest scores obtained in all domains among workers were from those in hospital $C$, which coincides with the largest number of occupational accidents, also reported by this hospital.

It is worth mentioning that, although hospital $C$ presents the largest number of employees in relation to the number of beds, it is the only institution exclusively attending SUS users, with the greatest budget restriction and the worst work conditions. It additionally provides urgent pre-hospital care to the city's community, which implies higher demand and complexity of care. This profile can, in part, contribute to the highest occurrence rates of occupational accidents and the lowest HRQoL scores among its workers.

Further studies with larger samples and control groups (non-injured subjects), with a longitudinal design and follow-up of injured workers as from the moment of the accident, using specific instruments, can contribute to verify the relation between occupational accidents and health workers' HRQOL.

\section{CONCLUSION}

The obtained results lead to the conclusion that there were no differences in the occurrence of occupational accidents among workers from the studied hospitals, public and/or private, between 2000 and 2005. In the same way, differences in HRQL were not found in health workers injured in 2005.

\section{FINAL CONSIDERATIONS}

Unhealthy work conditions are currently found in the majority of hospitals, including those in big cities, which affects the number of occupational accidents. Thus, the great challenge is to balance work conditions and optimize workers health. Data from this study, however, evidenced high average scores in all HRQoL domains among health workers. Differences in injured workers' HRQoL were not found, neither in public nor private institutions. Further research, with specific methodological design and instruments, is needed in order to deepen the investigation about the extent to which the injured workers' HRQoL is affected, as well as how occupational accidents affect health workers' HRQoL. 


\section{REFERENCES}

1. Benatti MCC. Acidentes do trabalho em um hospital universitário: um estudo sobre a ocorrência e os fatores de risco entre trabalhadores de enfermagem. [Tese]. São Paulo (SP): Escola de Enfermagem/USP; 1997.

2. Whoqol Group. The development of the world health organization quality of life assessment instrument (the WHOQOL) In: Orley J, Kuyken W, editors. Quality of life assessment: international perspectives. Heigelberg: Springer Verlag; 1994.

3. Auquier P, Simeoni MC, Mendizabal H. Approaches théoriques et méthodologiques de la qualité de vie a la santé. Rev Prevenir 1997; 33: 77-86.

4. Ware JE, Sherbourne CD. The MOS 36- Item Short-Form Health Survey (SF-36). Med Care 1992; 30(6):473-83.

5. Ciconelli RM, Ferraz MB, Santos W, Meinão I, Quaresma MR. Tradução para a língua portuguesa e validação do questionário genérico de avaliação de qualidade de vida SF36. Rev Bras Reumatol 1999; 39(3):143-50.

6. Nunnally JC. Psychometric theory. New York: McGrawHill; 1978.

7. Balsamo AC. Estudo sobre os acidentes do trabalho com exposição aos líquidos corporais humanos em trabalhadores da saúde. [Dissertação]. São Paulo (SP): Escola de Enfermagem/USP; 2002.
8. Marziale MHP, Rodrigues CM. A produção científica sobre acidentes de trabalho com material perfurocortante entre trabalhadores de enfermagem. Rev Latino-am Enfermagem 2002 julho; 10(4):571-7.

9. Souza M. Acidentes ocupacionais e situações de risco para a equipe de enfermagem: um estudo em cinco hospitais do município de São Paulo. [Tese]. São Paulo (SP): Escola Paulista de Medicina/ UNIFESP; 1999.

10. Silva VEF. Estudo sobre acidentes de trabalho ocorridos com trabalhadores de enfermagem de um hospital de ensino. [Dissertação]. São Paulo (SP): Escola de Enfermagem/USP; 1988 .

11. Canini SRMS, Gir E, Hayahida M, Machado AA. Acidentes perfurocortantes entre trabalhadores de enfermagem de um hospital universitário do interior paulista. Rev Latino-am Enfermagem 2002 março/abril; $10(2): 172-8$.

12. Gurgueira GP Contribuições ao estudo de qualidade de vida e restrições de trabalho em uma instituição hospitalar. [Dissertação-Mestrado]. Campinas: Faculdade de Ciências Médicas, Universidade Estadual de Campinas; 2005

13. Oliveira APBM. Qualidade de vida e sintomas osteomusculares em médicos de um hospital universitário. [Dissertação-Mestrado]. Campinas: Faculdade de Ciências Médicas, Universidade Estadual de Campinas; 2004. 